\title{
Inclusion Exclusion Criterion Collection Date Time
}

National Cancer Institute

\section{Source}

National Cancer Institute. Inclusion Exclusion Criterion Collection Date Time. NCI

Thesaurus. Code C83295.

The date and time inclusion and exclusion criterion data was collected. 